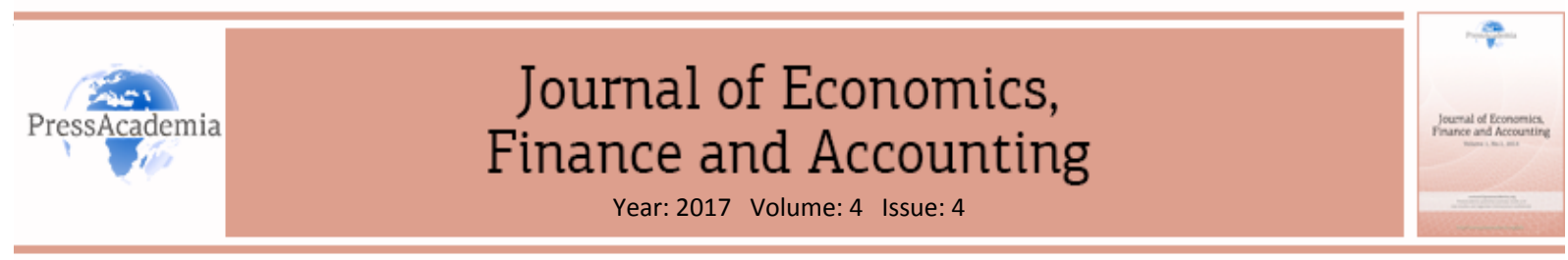

\title{
DETERMINANTS OF BANK PROFITABILITY: EVIDENCE FROM LISTED AND NON-LISTED BANKS IN TURKEY
}

\author{
DOI: 10.17261/Pressacademia.2017.750 \\ JEFA-V.4-ISS.4-2017(5)-p.404-416
}

\section{Murat Belke ${ }^{1}$, Esra Aydin Unal ${ }^{2}$}

${ }^{1}$ Mehmet Akif Ersoy University, Department of Economics, Burdur, Turkey. muratbelke@gmail.com

${ }^{2}$ Cumhuriyet University, Department of Insurance and Risk Management, Sivas, Turkey. eaunal@cumhuriyet.edu.tr

\section{To cite this document}

Belke, M., Unal, E.A. (2017). Determinants of bank profitability: evidence from listed and non-listed banks in Turkey. Journal of Economics, Finance and Accounting (JEFA), V.4, Iss.4, p.404-416.

Permemant link to this document: http://doi.org/10.17261/Pressacademia.2017.750

Copyright: Published by PressAcademia and limited licenced re-use rights only.

\section{ABSTRACT}

Purpose - The aim of this study is to determine the bank-specific, sector-specific and macroeconomic factors that affect the profitability of 23 deposit banks in Turkey.

Methodology- in this study, we employ panel regression analyzes as well as mean and median tests. Our study using quarterly data covering the period 2005Q1-2015Q4 is divided into two groups: listed banks and non-listed banks.

Findings- According to the results of the mean and median tests, there are significant differences between the listed banks and non-listed banks in terms of bank-specific variables. Regression results also indicate that the bank profitability is significantly affected by the variables such as bank size, bank capital, liquidity risk, economic growth, inflation, policy rate, exchange rate, and market concentration.

Conclusion- When our results are evaluated in general, it could be said that the factors affecting profitability significantly differ according to whether the banks are traded at the Borsa Istanbul.

Keywords: Turkish banking sector, deposit banks, determinants of profitability, Borsa Istanbul, Turkey. JEL Codes: C23, E44, G21.

\section{BANKA KARLILIĞININ BELIRLEYICILERI: TÜRKIYE'DE BORSAYA KOTE OLAN VE OLMAYAN BANKALARDAN KANITLAR}

\section{ÖZET}

Amaç- Bu çalışmanın amacı Türkiye'deki 23 mevduat bankasının karlılığı üzerinde etkili olan bankaya özgü, sektöre özgü ve makroekonomik faktörlerin belirlenmesidir.

Yöntem- 2005Ç1-2015Ç4 dönemini kapsayan çalışmada karlılık belirleyicilerinin incelenmesinde ortalama ve medyan testlerinin yanı sıra panel regresyon analizleri kullanılmıştır. Analizde bankaların borsada işlem görme durumlarına göre örneklem iki gruba ayrılmıştır.

Bulgular- Ortalama ve medyan testleri sonuçlarına göre, bankaya özgü değişkenler açısından borsada işlem gören ve görmeyen bankalar arasında anlamlı farklılıklar bulunmaktadır. Ayrıca regresyon sonuçları bankaların aktif karlılı̆ının banka büyüklüğü, banka sermayesi, likidite riski, ekonomik büyüme, enflasyon, politika faiz oranı, döviz kuru ve piyasa yoğunlaşması gibi değişkenlerden anlamlı bir şekilde etkilendiğini göstermektedir.

Sonuç- Analiz sonuçlarımız genel olarak değerlendirildiğinde bankaların aktif karlılı̆ı üzerinde etkili olan faktörler bankaların borsada işlem görme durumlarına göre anlamlı farklılıklar göstermektedir.

Anahtar Kelimeler: Türk bankacılık sektörü, mevduat bankaları, karlılığın belirleyicileri, Borsa İstanbul, Türkiye. JEL Kodları: C23, E44, G21. 


\section{GiRiş}

Finansal sistem, ekonomik kalkınma sürecinde tasarrufların yatııılara yönlendirilmesini ve aktarılmasını sağlamaktadır. Finansal aracılar, ödünç alan ve veren arasındaki bilgi asimetrisini düşürerek fonları en verimli kullanılacağı alana tahsis etmekte, böylece tasarrufların net getirisini ve yatırımların brüt getirisini arttırarak ekonomik etkinliğin ve sosyal refahın arttırılmasına katkıda bulunmaktadır. Bu yönüyle finansal sistem, sermaye birikimi, toplam faktör verimliliği ve ekonomik büyüme sürecinde önemli aracılık rolünü üstlenmektedir (King ve Levine, 1993; Levine, 1997; Demirgüç-Kunt ve Huizinga, 1999; Fase ve Abma, 2003).

Bankalar ekonominin işleyişinde merkezi bir rol oynamaktadır. Ayrıca sağlam bir bankacılık sistemi sürdürülebilir ekonomik kalkınma açısından da büyük önem taşımaktadır. Bankacılık sektörü, mevduatları verimli yatırımlara dönüştürerek finansal aracılık ve ekonomik ivme sağlama konusunda önemli bir ekonomik fonksiyonu yerine getirmektedir. Bu bağlamda, bankalar önemli fon sağlayıcılarıdır ve bankacılık sektörünün istikrarı finansal sistem için önemli ve kritiktir (Menicucci ve Paolucci, 2016; Isik, 2017). Bankacılık sektörünün istikrarı da yeterli miktarda bankacılık karlılı̆ı̆ı gerektirmektedir (Demirgüç-Kunt ve Huizinga, 1999). Bu nedenle finansal sistemin en önemli parçası olan bankacılık sektörünün performansını ve karıı̆ı̆ını etkileyen faktörlerin incelenmesinin önemli politika etkileri bulunmaktadır.

Hem dış hem de ülkeye özgü faktörler bankacılık sektörünün yapısını ve performansını etkilemektedir. Sağlam ve karlı bir bankacılık sektörü olumsuz şoklara karşı bankaların direnç gösterme kabiliyetini arttırmakta ve finansal sistemin istikrarına katkıda bulunmaktadır (Athanasoglou vd., 2008). Buna karşın 2007-2008 küresel finans krizi sektördeki bir bankada meydana gelen olumsuzlukların sektörün ve finansal sistemin istikrarını bozarak sistemik bir riske dönüşebileceğini, ekonominin yavaşlamasına ve işsizlikte artışa neden olabileceğini göstermiştir (Isik ve Bolat, 2016). Bu nedenle banka performansının ve özellikle karlıı̆ı̆ belirleyicileri, akademik araştırmaların yanı sıra sektöre yön veren politika yapıcılar, düzenleme ve denetleme kurumları ve özellikle banka politikalarına yönelik kararlar veren banka yönetimleri tarafından da artan oranda ilgiye maruz kalmaktadır.

Mikro düzeyde bakıldığında bir firmanın büyümesi ve varlığını sürdürmesi elde edebileceği kara bağlıdır. Küreselleşme sürecinde uluslararası banka girişleri yerel bankalar üzerindeki baskıyı ve rekabeti arttırarak kar marjlarını düşürmüştür. Bu açıdan bakıldığında, kar rekabetçi bir bankacılık sektörünün ön koşuludur. Kar sadece artan rekabet dönemleri için değil, başarılı iş fırsatları açısından da önem taşımaktadır. Bu nedenle banka yönetimlerinin temel amacı kar elde etmek ve bunu sürdürebilmektir. Bankaların kârlılık performansı, banka yönetiminin başarısını yansıtması nedeniyle yatırımcıların en önemli performans göstergelerinden biridir. Kârlılığın artması, hissedarların yatırım büyüklüğündeki artışın en önemli faktörüdür. Bu nedenle karlılığın belirleyicilerin belirlenmesi, hem banka yönetimlerinin başarısı hem de mevcut ve potansiyel ulusal ve uluslararası yatırımcılar açısından kritik öneme sahiptir (Menicucci ve Paolucci, 2016; Isik, 2017).

Türkiye ekonomisinin son 20 yılına baktığımızda bankacılık sektörü içsel ve dışsal faktörlerin etkisiyle büyük dönüşümler ve değişimler yaşamıştır. Bu sürecin sektörün performansı ve karlılığı üzerinde de doğrudan etkileri olmuştur. Türkiye'de görülen Kasım 2000 ve Şubat 2001 krizlerinin ardından ortaya çıkan yeni makroekonomik çerçeve bankacılık sektöründe önemli değişikliklere neden olmuştur. Faiz oranlarındaki artış, Türk Lirasının değer kaybı ve ekonomik daralma bankaların karlıı̆ını ters yönde etkilemiştir. Kriz sonrası uygulamaya konan Bankacılık Sektörü Yeniden Yapılandırma Programıyla birlikte bankaların sermaye yapıları güçlendirilmiş, vergi teşvikleriyle de desteklenen birleşme ve satın alma faaliyetleri sektörde yoğunlaşmayı arttırmıştır (Abbasoglu vd., 2007). Ayrıca bankacılık sektörü reformları, ihtiyati düzenleme ve bankacılık sektörünün denetimi için önlemler içermekteydi. Türk Bankacılık Sistemi, 2001 krizi sonrasında uygulamaya konan reformlar ve BDDK, Merkez Bankası gibi finansal otoriteler tarafından etkin yönetimi, 2007-2008 küresel finansal krizin olumsuz etkilerinden korunmasını sağlamıştır. Ancak ekonomideki daralma ve küresel sistemdeki istikrarsızık Türk Bankacılık Sektörünü de etkilemiştir. TCMB, küresel kriz sonrası ortaya çıkan finansal istikrarsızlık durumuna karşı para politikası çerçevesini genişleterek finansal istikrarı tamamlayıcı bir hedef olarak benimsemiş ve böylece Türk Bankacılık Sektörünün krizin yarattığı istikrar bozucu yayılım etkilerine karşı direncini arttırmaya çalışmıştır. TCMB, dış dengedeki bozulma ve sermaye akımlarındaki oynaklıktan kaynaklanan makro finansal riskleri azaltmayı hedefleyerek politika araçları kümesine kısa vadeli faiz oranlarına ilave olarak zorunlu karşılılar, faiz koridoru, likidite yönetimi ve rezerv opsiyonu mekanizmasını eklemiştir (Baş̧̧ı ve Kara, 2011; Us, 2015).

Türk bankacılık sektörü hem 2000 Kasım-2001 Şubat krizlerinin ardından hem de küresel finansal kriz sonrasında önemli yapısal değişimlerle ve reformlarla karşı karşıya kalmıştır. Bu nedenle çalışmanın temel amacı Türkiye'de finansal sistemin en önemli parçasını oluşturan bankacılık sektöründe 2005Q1-2015Q4 dönemi için bankaların karlıı̆ının belirleyicilerinin incelenmesidir. Çalışmanın mevcut literatüre katkısı bankacılık sektöründe yapısal değişimin ve dönüşümün etkilerinin incelenmesini sağlayan uzun bir dönemi ele almasının yanı sıra, banka karııığını etkileyebilecek banka-temelli, bankacılık sektörü-temelli, makroekonomik ve politika ilintili muhtemel tüm değişkenleri kullanarak mevcut çalışmaların genişletilmesidir. Ayrıca bu çalışma bankaların Borsa İstanbul'a kote olup olmamalarına bağılı olarak iki alt gruba ayırarak 
banka karlıı̆ı̆ın belirleyicilerini inceleyen ilk çalışmadır. ${ }^{1}$ Son olarak bu çalışma bankaların maruz kaldıkları önemli risklerden biri olan likidite riskini direk inceleyen sınırlı sayıda çalışmadan birisidir. Ortalama ve medyan testleri sonuçları göstermektedir ki bankaya özgü değişkenler açısından borsada işlem gören bankalar ile diğer bankalar arasında anlamlı farklılıklar bulunmaktadır. Ayrıca, regresyon sonuçlarına göre bankaya özgü (banka büyüklüğü, banka sermayesi ve likidite riski) makro (ekonomik büyüme, enflasyon, politika faiz oranı ve döviz kuru) ve sektöre özgü (piyasa yoğunlaşması) değişkenler banka karlııı̆ındaki değişimi açıklayan önemli değişkenlerdir. Ayrıca, çalışmanın bulguları göstermektedir ki mevduat bankalarının borsada işlem görme durumu göz önüne alındığında karlılı̆ının belirleyicileri anlamlı olarak farklılaşmaktadır.

Çalışma beş bölümden oluşmaktadır. Giriş bölümünde konunun tanıtımı ve önemi vurgulanmaktadır. İkinci bölümde banka karlılığını etkileyen faktörleri inceleyen ampirik çalışmalar özetlenmiş, üçüncü bölümde ise veri seti, değişkenler ve ekonometrik yöntem tanıtılmışır. Dördüncü bölümde ampirik bulgular değerlendirilmiştir. Çalışmanın son bölümünde çalışmadan elde edilen sonuçlar ve sonuçların etkilerine yönelik politika önermelerine yer verilerek çalışma tamamlanmıştır.

\section{LITERATÜR TARAMASI}

Literatürde, banka kârlıığı genellikle içsel ve dışsal belirleyicilerin (faktörlerin) bir fonksiyonu olarak ifade edilmektedir. Karlıı̆ın içsel belirleyicileri, mikro veya bankaya özgü belirleyiciler olarak adlandırılabilmektedir. Dışsal belirleyiciler ise, banka yönetimiyle ilgili olmayan, fakat finansal kurumların faaliyet ve performansını etkileyen ekonomik ve hukuki ortamı yansıtan değişkenlerdir. Literatürdeki çalışmalar, araştırmanın niteliğine ve amacına göre, her iki kategoride de açıklayıcı değişkenler kullanmıştır (Athanasoglou vd., 2008).

Bankacılığın karlııı̆ının belirleyicilerini inceleyen çalışmalar, iki grupta değerlendirilebilmektedir. İlk grup çalışmalar (Short, 1979; Bourke, 1989; Molyneux ve Thornton, 1992, Demirgüç-Kunt ve Huizinga, 1999; 2000; Goddard vd., 2004a; 2004b) geniş sayıdaki yatay-kesit ülke setini kullanmaktadırlar. İkinci gruptaki çalışmalarsa ülke bazlı (Williams, 2003; Athanasoglou vd. 2008; Dietrich ve Wanzenried, 2011; Us, 2015) çalışmalardır. Bu gruptaki çalışmalar heterojen ülke seti yerine yalnızca tek bir ülkeye ait bankacılık sektöründe karlıığın belirleyicilerini incelemektedir. Her iki gruptaki çalışmalar hem bankatemelli, hem sektör-temelli hem de makroekonomik belirleyicilere ilişkin veri setini kullanmaktadırlar.

Literatürdeki ilk çalışmalardan biri olan Short (1979), bankacılık sektöründeki yoğunlaşmanın, sahiplik yapısının ve banka büyüklüğünün karlıık üzerine etkilerini incelemiştir. Short (1979), 12 gelişmiş ülkedeki (Kanada, Japonya ve Batı Avrupa ülkeleri) 60 bankada (1972-1974 dönemi) banka büyüklüğünün ve sektördeki artan yoğunlaşmanın banka karlılığını arttırdığı sonucuna ulaşmıştır. Ancak Short (1979) yoğunlaşma katsayısının nispeten küçük olması nedeniyle kar oranlarını arttırmak için yoğunlaşmada büyük değişikliklerin olması gerektiğini ileri sürmektedir. Ayrıca sonuçlar banka sahiplik yapısının da karlılık üzerinde anlamlı etkileri bulunduğunu göstermektedir. Short'un (1979) bulgularına göre, özel sahiplik yapısına sahip bankalar daha yüksek kar sağlamaktadır. Aksine Smirlock (1985), ABD bankacılık sektöründeki yoğunlaşma ve karlılık arasında ilişkiye yönelik ampirik kanıtlar sunamamıştır. Ancak yoğunlaşmanın kontrol edildiği durumda piyasa payı ile karlıık arasında pozitif ilişki bulunmaktadır. Smirlock'un (1985) banka büyüklüğünün karlılığı pozitif etkilediğini gösterdiği sonuçlar, Short'un (1979) bulgularıyla örtüşmektedir. Bourke (1989), Short'un (1979) çalışmasını 90 banka ve 10 yıllık dönemle (19721981) genişletmektedir. Çalışmada Avrupa, Kuzey Amerika ve Avusturalya kıtasından toplam 12 bölge bulunmaktadır. Bulgulara göre sermaye oranı, likidite oranı, enflasyon oranı, faiz oranı ve piyasadaki büyümeyi gösteren para arzı büyüme oranı ile karlıık arasında pozitif ilişki bulunmaktadır. Ancak Short'un (1979) aksine sahiplik yapısı ve karlılık arasında ilişki yoktur. Ayrıca yoğunlaşmanın karlıığa pozitif etkisine ilişkin kanıtlar bulunmakla birlikte, etki kullanılan karlıık göstergesine göre değişmektedir. Avrupa bankacılık sektöründe bankaların karlılığını incelemek için Bourke'nin (1989) çalışmasını tekrarlayan Molyneux ve Thornton (1992), 18 Avrupa ülkesinde 1986-1989 dönemi için bankaların sermaye getirisi (birinci karlılık ölçüsü) ile yoğunlaşma ve faiz oranları arasında pozitif ilişkiye ulaşmıştır. Ancak sahiplik yapısına ilişkin bulgular Short (1979) ve Bourke'nin (1989) aksine kamu sahipliği ile karlılık arasında anlamlı ve pozitif bir ilişkinin olduğunu öne sürmektedir. Kamu bankaları, özel bankalara nispeten daha yüksek sermaye getirisi sağlamaktadır. Molyneux ve Thornton (1992) bu şaşırtıcı sonucu örneklemdeki kamu bankaların ağırlığına bağlamaktadır. Aktif karıı̆ı̆ının alternatif karlılık göstergesi olduğu durumda, sermaye oranı ve faiz oranları karlılıkla pozitif ilişkilidir. Bulgular Bourke'nin (1989) bulgularıyla örtüşmektedir. Ancak likidite oranı ile karlıık arasındaki ilişki negatiftir. Ayrıca kamu sahipliğinin ve yoğunlaşmanın karlılığa etkisi alternatif karlıık göstergesi altında da pozitiftir. Enflasyonun karlılığa etkisi pozitif olmakla birlikte, alternatif karlılık göstergeleri altında etki farklılaşmaktadır.

Demirgüç-Kunt ve Huizinga (1999), 80 gelişmiş ve gelişmekte olan ülkede 1988-1995 dönemi için banka-seviyesinde panel veri analizini kullanarak karlılığın yalnızca banka-temelli göstergelere (büyüklük, banka sermayesi, kaldıraç, iş farklılı̆̆ ve

\footnotetext{
${ }^{1}$ Dietrich ve Wanzenried (2011) banka hissedarlarının, finansal analistlerin ve piyasa katılımcılarının borsada işlem gören bankaların kar oranlarının daha yüksek olmasını beklediğini belirtmektedir. Ayrıca, borsada işlem gören bankaların faaliyet sonuçları ile ilgili raporlama süreçleri ve diğer yükümlülükleri bu tür bankaların maliyetlerini arttırabilmektedir. Dolayısıyla borsada işlem gören bankaların hem maruz kaldıkları baskılar hem de artan maliyetleri iki tür bankanın karlılığııı etkileyen faktörlerin farkılıaşmasına yol açabilmektedir.
} 
sahiplik yapısı) değil, vergileme, düzenleme, kurumsal ve yasal düzendeki (sözleşme uygulanabilirliği, hukukun üstünlüğü ve yasal düzen ve yolsuzluk) farklııklarla da açıklanabileceğini göstermektedir. Çalışmayı finansal yapıdaki (bankacılık-temelli ve piyasa-temelli finansal sistem) farklılı̆ın etkileri ile genişleten Demirgüç-Kunt ve Huizinga (2000), finansal yapının karlıık üzerinde bağımsız bir etkisinin bulunmadı̆̆ını, az gelişmiş finansal sistemlere sahip ülkelerde ise banka karlarının anlamlı olarak daha yüksek olduğunu ileri sürmüşlerdir. Gelişmiş bankacılık sektöründeki bankalar daha fazla rekabete maruz kalmaları nedeniyle daha düşük karııı̆a sahiptir. Ayrıca her iki çalışmada da enflasyonun karlıık üzerinde pozitif etkisi bulunmaktadır.

Bikker ve Hu (2002), 1979-1999 döneminde 26 OECD ülkesinde alternatif karlııık ölçüleri (aktif karlılığı ve özkaynak karlılığı) altında banka karlarının devresel dalgalanmalarla ilişkili olduğu sonucuna varmışlardır. Sonuçlar, karlıı̆ın reel ekonomik büyümenin \%2'nin üzerinde olduğu durumda \%2'nin altında olduğu duruma nispeten iki buçuk kat daha yüksek olduğunu göstermektedir. Ampirik sonuçlar banka büyüklüğü ile karlılık arasında pozitif ilişki bulan Short (1979) ve Molyneux ve Thornton'u (1992) desteklemektedir. Makroekonomik göstergelerden işsizlik negatif, ekonomik büyüme ve enflasyon ise pozitif etkilemektedir. Bulgular enflasyon seviyesinin ve büyüme oranının karlılığı pozitif etkilediğini rapor eden DemirgüçKunt ve Huizinga'nın (1999) bulgularını desteklemektedir. Çalışmada beklenenin aksine krediler ve kar marjları arasındaki ilişki negatiftir. Sermaye ve rezervler ise anlamlı olarak pozitif etkilemektedir. Çalışmada pay fiyatlarının, reel para arzının ve bankacılık dışı mevduatların karlılık üzerinde bir etkisi bulunmamaktadır. Çalışmanın bulguları ülke setinin daraltılması ve dönemin Basel-I öncesi (1979-1990) ve Basel-I sonrası (1991-1999) olarak ayrılması durumunda da tutarlıdır. Jansen ve Haan (2003) ise ülke düzeyinde panel verileri kullanarak Avrupa bankacılık sektöründe banka karlılığının, alternatif rekabet göstergeleri altında rekabet ile ilişkili olmadığı sonucuna vurgu yapmıştır. Demirgüç-Kunt ve Huizinga'nın (1999) bulgularının aksine yoğunlaşma ve karlılık arasında sağlam bir pozitif ilişki bulunmamaktadır. Rekabet ve karlılık arasında ilişki bulunmazken, faiz oranları ile negatif bağlantı bulunmaktadır. Ayrıca enflasyon ve GSYH'nın karlılık üzerinde pozitif etkisi bulunmaktadır.

Avrupa Birliği üyesi beş büyük ülkede (Fransa, Almanya, İtalya, İspanya ve İngiltere) karlılığın belirleyicilerini inceleyen Goddard vd. (2004a), alt örneklemler için banka büyüklüğü ile özkaynak karlılı̆̆ arasında ilişki olmasına rağmen sağlam bir ilişkiye ulaşılamadığını rapor etmektedir. Dinamik panel regresyonundan elde edilen sonuçlar sermaye-aktif oranının, yataykesit regresyondan elde edilen sonuçlarsa likidite oranının banka karlıı̆̆ını negatif etkilediğini göstermektedir. Bu sonuç daha riskli bankaların daha karlı olduğunu göstermiştir. Piyasa payı birçok modelde karlılıkla negatif ilişkiliyken, ekonomik büyüme ve yoğunlaşma tüm örneklem için dinamik panel sonuçlarına göre pozitif etkilemektedir. Goddard vd. (2004a) karlılık üzerinde bankacılık sektörünün yapısına (piyasa yoğunlaşması) ilişkin ölçülerin banka-temelli etkinlik göstergelerinden daha önemli olduğunu ileri sürmüşlerdir. Aynı zamanda karların kalııılığını inceleyen çalışma, kalıcılığın banka faaliyet alanına göre farklılaştığını, tasarruf ve kooperatif bankaları için karların kalıcılığının anlamlı olarak daha yüksek olduğunu bulmuşlardır. Bu çalışmayı Danimarka’yı da içerecek şekilde genişleten Goddard vd. (2004b), bankacılık sektöründe 1992-1998 döneminde karların (aktif karlılığı) kalıcılığının anlamlı olduğunu göstermiştir. Banka büyüklüğükarılık ilişkisine ilişkin ülke bazında farklı sonuçlara ulaşan çalışma sağlam ve ikna edici bir ilişkinin bulunmadığını, banka etkinliğinin büyüklüğe nispeten daha önemli olduğunu iddia etmektedir. Sermaye-aktif oranı ve karlılık arasında pozitif ilişki bulunurken, bilanço dışı yükümlülüklerdeki artış yalnızca İngiltere'de anlamlı pozitif etkiye sahiptir. Panel veri analizi sonuçlarına göre bankaların sahiplik yapısındaki farklılık Alman bankacılık sistemi için önemlidir. Bulgular Goddard vd.'nin (2004a) bulgularıyla benzerlikler göstermektedir. Küresel finansal kriz sonrası Avrupa'daki 35 büyük bankanın karııı̆ını alternatif karlılık göstergeleriyle inceleyen Menicucci ve Paolucci (2016), banka büyüklüğünün ve sermaye oranın pozitif, kredi riski karşılıklarının negatif etkili olduğu sonucuna ulaşmışlardır.

Ülke bazlı çalışmalar genellikle ABD ve gelişmiş ülkelere odaklanmakla birlikte, son yıllarda artan oranda yükselen piyasa ekonomileri ve diğer gelişmekte olan ülkelerdeki bankaların karlılı̆ına ilişkin çalışmalar bulunmaktadır. Bankaların karlılı̆ı (aktif karlı|ı̆ı) üzerinde kredi portföyünün etkilerini de dikkate alan Miller ve Noulas (1997), ABD'deki büyük ticari bankaların düşük performansını kredi portföyünün kalitesindeki düşüşe bağlamaktadır. Hem yatay-kesit hem de panel veri analizini kullanan çalışmanın bulguları, emlak kredilerinin karılık üzerinde negatif, inşaat, arazi ve tüketici kredilerinin ise pozitif etki gösterdiğini rapor etmiştir. Ayrıca sonuçlar banka büyüklüğünün (toplam varlıklar), kredi kayıp karşılıklarının toplam kredilere oranının ve faiz dışı giderlerin toplam giderler içindeki payının karlılıkla negatif ilişkili olduğunu göstermektedir. Çalışan başına maaş ve yardımların oranı, faiz dışı gelirin toplam gelir içindeki payı, toplam kredilerin toplam varlıklara oranı, toplam mevduatların toplam varlıklara oranı ve toplam işlem mevduatlarının toplam mevduatlar içindeki payının artışı banka karlılı̆ını pozitif etkilemektedir.

Avustralya'da yabancı bankaların ülkeye özgü ve uluslararası belirleyicilerini inceleyen Williams (2003), ev sahibi ülkedeki yoğunlaşmanın yabancı banka girişleri için etkin bir engel olduğunu, bu nedenle yoğunlaşmanın yabancı bankaların karlıı̆ını düşürdügünü göstermiştir. Çalışmaya göre bu sonuç, yerli ve çok uluslu bankalar arasında eksik bir entegrasyon olduğunu göstermektedir. Yabancı bankaların büyüklüğündeki artış uzun dönemde karlılığı arttırırken, yerli rakiplerinin piyasa payındaki artış karlıı̆̆ı düşürmektedir. Ayrıca Avustralya'nın büyüklüğündeki ve büyümesindeki artış karılılğa pozitif katkıda bulunmaktadır. Tek bir ülkeye özgü bankacılık sektörünü inceleyen en ayrıntılı çalışmalardan biri Athanasoglou vd. (2008) 
tarafından yapılmıştır. Yunanistan bankacılık sektörünü inceleyen Athanasoglou vd. (2008), banka-temelli (operasyonel etkinlik, finansal risk ve büyüklük), sektör-temelli (yoğunlaşma ve sahiplik yapısı) ve makroekonomik yapıya (devresel çıktı ve beklenen enflasyon) ilişkin değişkenleri ve dinamik panel GMM yönetimini kullanmıştır. Ampirik model Yapı-IşsleyişPerformans hipotezini içerecek şekilde oluşturulmuştur. Bulgular büyüklük dışındaki banka-temelli ölçülerin (karlılığı sermaye, emeğin verimliliğindeki büyüme pozitif, kredi riski, operasyon giderleri negatif etkilemektedir) karlılık üzerinde anlamlı etkilere sahip olduğunu, karlılı̆ın konjonktürle aynı yönde hareket ettiğini ve etkinin yalnızca konjonktürün yükselme dönemlerinde asimetrik olduğunu göstermektedir. Ayrıca beklenen enflasyondaki artış banka karılı̆̆ını arttırmaktadır. Banka sahipliğinin karlılık üzerinde etkisi bulunmazken, sektördeki yoğunlaşmanın negatif ancak anlamsız etkisi bulunmaktadır. Ancak sektör-temelli göstergelerin karlıık üzerinde etkisi bulunmadığını ileri sürmüşlerdir. Karların kalıcılığına ilişkin Avrupa bankalarında zayıf kanıtlara ulaşan Goddard vd.'nin (2004b) aksine güçlü kanıtlar sunmaktadır.

Türk bankacılık sektöründe karlılığın belirleyicileri inceleyen Abbasoglu vd. (2007), sektörde birleşme ve satın almaların arttığı 2001-2005 döneminde karlıık ölçüleriyle (ROE ve ROA) etkinlik arasında açık bir ilişki bulunmadığını ileri sürmektedir. Ancak sonuçlar, inceleme döneminde yabancı bankaların karlılığının yerli rakiplerine nispeten daha yüksek olduğunu ve yabancı bankaların etkinliğinin düşük olmasına rağmen daha karlı olduğunu göstermektedir. Türk bankacılık sistemindeki tüm ticari bankaları analizine dahil eden Taşkın (2011), aktif karlılığı ve özkaynak karlılığı değişkenlerini kullanarak banka karlılığının makroekonomik faktörlere nispeten banka-temelli göstergeler tarafından açıklanabileceğini ileri sürmüştür. 1995-2009 dönemindeki panel veri analizi sonuçları, alternatif karlılık göstergeleri altında takipteki kredilerin toplam krediler içindeki payının artışının karlıı̆̆ negatif, bilanço dışı faaliyetlerin toplam aktifler içindeki payının ise pozitif etkilediğini göstermiştir.

Alper ve Anbar (2011) ise 2002-2010 döneminde banka büyüklüğünün hem özkaynak hem de aktif karlılığını anlamlı bir şekilde pozitif etkilediğini rapor etmiştir. Uludağ ve Gökmen (2011) aktif büyüklüğü ve özsermaye düzeyi ile karlılık arasında anlamlı bir ilişki bulunduğunu, aktif büyüklüğü ve özsermayesi düşük olan bankaların anlamlı olarak daha yüksek karlar elde ettiğini belirtmişlerdir. Makroekonomik değişkenlerin etkilerine bakıldığında hem enflasyon hem de ekonomik büyüme banka karlıı̆ıını pozitif etkilemektedir. Sistem-GMM yaklaşımını kullanan Turgutlu (2014) Türk bankacılık sektöründe karların kalıcılığının yüksek olduğunu, ilişkinin alternatif karlıık göstergeleri altında tutarlı olduğunu göstermektedir. Bankatemelli belirleyicilerin anlamlılığı alternatif karlılık göstergeleri altında değişmekle birlikte, her iki karlılık göstergesi altında yönetimsel etkinliği temsil eden toplam işlem maliyetlerinin toplam gelir içindeki payının ve bilanço dışı yükümlülüklerin artışı karlııkla negatif, bankanın finansal sağlamlığını gösteren Z-skorundaki artış ise pozitif ilişkilidir.

Us (2015), Türk bankalarının karlılı̆ını 2002Q4-2013Q3 dönemindeki 21 mevduat bankasında hem kriz öncesi hem de kriz sonrası dönem için banka-temelli, makroekonomik ve politikayla ilişkili değişkenleri kullanarak incelemiştir. Panel veri analizi sonuçları, döviz açık pozisyonunun kriz öncesi dönemde aktif karlılığı göstergesi üzerinde negatif, kriz sonrası dönem için ise pozitif etkisi bulunduğunu, ayrıca banka büyüklüğünün karlılığı negatif etkilediğini göstermektedir. Döviz kurunun ve banka yaşının kriz sonrası dönem için etkisi negatifken, politika oranının ve Türk Lirası zorunlu karşııklarının etkisi pozitiftir. Çalışmada banka sahipliğinin, borsada işlem görme durumunun, ekonomik büyümenin, enflasyonun ve döviz zorunlu karşılıklarının karlıık üzerinde anlamlı bir etkisi bulunmamaktadır.

Türk bankacılık sektörüne yönelik güncel bir çalışmada mevduat bankalarını mülkiyet yapılarına göre üç gruba ayıran Isik (2017), sermaye oranı, gelir çeşitliliği, banka büyüklüğü, istikrar düzeyi, kredi riski, kredilendirme seviyesi, mevduat seviyesi ve faaliyet giderleri gibi bankaya özgü içsel değişkenlerin banka aktif karlılı̆ı üzerinde anlamlı etkilere sahip olduğunu rapor etmiştir.

Genel olarak değerlendirildiğinde banka karlıı̆ı̆ın banka-temelli, sektör-temelli ve makroekonomik belirleyicilerini inceleyen geniş literatür, farklı ülke grupları, bankacılık sektörü grupları, veri dönemi ve frekansları ve ampirik yöntemler kullanarak çok çeşitli sonuçlara ulaşmıştır. Bulgular, sadece çalışmalar arasında değil çalışmada kullanılan bağımlı ve bağımsız değişken tanımlarına göre bile farklılaşmaktadır. Ayrıca çok ülkeli çalışmalardan elde edilen sonuçlar ülkeler arasında genelleştirilememektedir. Çünkü ülkeler bankacılık sektörüne, finansal sektöre ve makroekonomiye yön veren politika uygulamaları ve bu uygulamaların başarıları açısından farklılık göstermektedirler.

\section{VERI SETI VE METODOLOJi}

\subsection{Veri}

Banka karlıı̆ıını etkileyen faktörlerin araştırıldığı bu çalışmanın kapsamı 2005Ç1-2015Ç4 döneminde Türk bankacılık sektöründe faaliyet gösteren 23 mevduat bankası ile sınırlıdır. Analize konu olan bankaların listesi Tablo 1'de sunulmaktadır. Karlılık modelinin tahmin edilmesinde kullanılan bankalara özgü veriler Türkiye Bankalar Birliği (TBB) web sitesinden, makroekonomik göstergelere ilişkin veriler ise Türkiye Cumhuriyeti Merkez Bankası (TCMB) ve Türkiye i̇statistik Kurumu (TÜiK) web sitesinden temin edilmiştir. 
Tablo 1: Analize Konu Olan Mevduat Bankaları

\begin{tabular}{llll}
\hline No & Borsada İşlem Gören Bankalar & No & Borsada İşlem Görmeyen Bankalar \\
\hline 1 & Akbank T.A.Ş. & 1 & Türkiye Cumhuriyeti Ziraat Bankası A.Ş. \\
2 & Alternatifbank A.Ş. & 2 & Turkish Bank A.Ş. \\
3 & Denizbank A.Ş. & 3 & Turkland Bank A.Ş. \\
4 & Finansbank A.Ş. & 4 & HSBC Bank A.Ş. \\
5 & ICBC Turkey Bank A.Ş. & 5 & ING Bank A.Ş. \\
6 & Şekerbank T.A.Ş. & 6 & Anadolubank A.Ş. \\
7 & Türkiye Garanti Bankası A.Ş. & 7 & Arap Türk Bankası A.Ş. \\
8 & Türk Ekonomi Bankası A.Ş.* & 8 & Burgan Bank A.Ş. \\
9 & Türkiye Halk Bankası A.Ş. & 9 & Citibank A.Ş. \\
10 & Türkiye İş Bankası A.Ş. & 10 & Deutsche Bank A.Ş. \\
11 & Türkiye Vakıflar Bankası T.A.O. & 11 & Fibabank A.Ş. \\
12 & Yapı ve Kredi Bankası A.Ş. & & \\
\hline
\end{tabular}

* Türk Ekonomi Bankası A.Ş. 2014 Kasım itibariyle Borsa İstanbul'dan çıkma kararı almıştır.

\subsection{Model Spesifikasyonu}

Mevduat bankaların karlıı̆ına etki eden faktörleri tespit etmek amacıyla kullanılan ekonometrik model aşağıdaki gibi formüle edilebilir:

Karlılık $_{\mathrm{iq}}=\beta_{0}+\beta_{1}$ BankayaÖzğ̈̈ $_{\mathrm{iq}}+\beta_{2}$ Makro $_{\mathrm{q}}+\beta_{3}$ Yoğunlaşma $_{\mathrm{q}}+\lambda_{\mathrm{i}}+\epsilon_{\mathrm{iq}}$

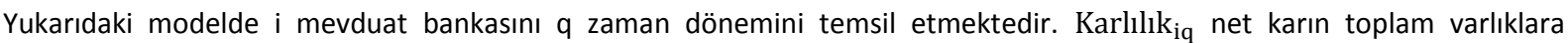
oranlanması ile ölçülmüş olup modelin bağımlı değişkenidir. $\beta_{0}$ sabit terimi; BankayaÖzğ $\ddot{u}_{\text {iq }}$ bankalara özgü değişkenleri; Makro $_{\mathrm{q}}$ makroekonomik değişkenleri ve Yoğunlaşma ${ }_{\mathrm{q}}$ piyasa yoğunlaşması değişkenini temsil etmektedir. $\lambda_{\mathrm{i}}$ bankalara özgü gözlenemeyen etkilerini ve $\epsilon_{\mathrm{iq}}$ hata terimini ifade etmektedir.

1 no'lu eşitlikte ifade edilen regresyon eşitliği öncelikli olarak bütün bankalar için tahmin edilmiştir. Ardından mevduat bankalarından oluşan örneklem bankaların borsada işlem görme durumuna göre iki ayrı alt-örnekleme ayrılarak tekrar analiz edilmiştir. Böylece banka karlılığını etkileyen faktörlerin bankaların borsaya kote olma durumuna göre değişip değişmediği sorgulanmıştır. Sonuçta 1 no'lu denklemde belirlenen model hem tüm bankalar örneklemi için hem de altörneklemler için ayrı ayrı tahmin edilmiştir. Analizde kullanılan bankalara özgü, makro ve sektöre özgü değişkenlere ilişkin tanımlar Tablo 2' de sunulmakta olup, bu değişkenlerin karlılık üzerinde beklenen etkileri aşağıdaki gibi detaylandırılabilir.

Banka büyüklüğü: bankacılık literatüründe banka büyüklüğünün banka karlılı̆ının önemli bir belirleyicisi olduğu konusunda bir fikir birliği vardır (Goddard vd., 2004a; 2004b; Barros vd., 2007; Uludağ ve Gökmen, 2011; Trujillo-Ponce, 2013; Menicucci ve Paolucci, 2016; Tan, 2016; Rashid ve Jabeen, 2016; Boadi vd., 2016; Işık ve Belke, 2017). Ölçek ekonomisi teorisine göre banka büyüklüğünün artması birim maliyetlerin azalmasına, operasyonel etkinliğin ve banka karlılığının artmasına neden olabilir. Ayrıca daha büyük bankalar ürün ve kredi çeşitlendirme yeteneği sayesinde maruz kaldıkları riskleri azaltarak kar performansını arttırabilirler. Ancak aşırı büyüklük bürokrasi ve hantallığa neden olabilir. Bu da vekalet maliyetleri ve diğer maliyetleri arttırarak kar düzeyinin azalmasına neden olur. Bu durumda banka büyüklüğü ile karlılık arasında ters yönlü bir ilişki beklenebilir.

Banka sermayesi: çalışmada banka sermayesini temsil etmek için toplam özsermayenin toplam varlıklara oranı kullanılmıştır. Bu değişken bankaların borçlanma düzeyini ve iflas riskinin bir göstergedir. Bankalar finansal aracılık faaliyetini yerine getirirken üstlendikleri riskler için yeterli düzeyde sermaye bulundurmak durumundadırlar. Sermaye düzeyi daha düşük olan bankalarla karşılaştırıldığında sermaye düzeyi daha yüksek olan bankalar beklenmeyen kayıplar ve olumsuz dış şoklar karşısında daha kolay çözüm üretebildiğinden bu değişken ile karlılık arasında pozitif bir ilişki beklenebilir. Ancak, risk-getiri dengesi hipotezine göre sermaye düzeyinin artması hem riskin hem de karlılığın azalmasına yol açabilir (Demirguc-Kunt ve Huizinga, 1999; Goddard vd., 2004a; 2004b; Athanasoglou vd., 2008; Djalilov ve Piesse, 2016; Ozili, 2017).

Kredi riski: banka karlıı̆ıının belirleyicileri üzerine yapılan önceki çalışmalarda en çok incelenen iki risk türünden biri olan kredi riski bu çalışmada takipteki kredilerin toplam kredilere oranlanması ile hesaplanmıştır. Bu değişken banka kredi portföy yapısının kalitesinin bir göstergesidir. Bu oranın artması bankaların maruz kaldığı kredi riskinin artması anlamına gelir. Teorik olarak kredi riskine maruz kalma düzeyi arttıkça banka karlıı̆ının azalması beklenir (Sufian ve Habibullah, 2009; Dietrich ve Wanzenried, 2014; Tan, 2016; Isik ve Ince, 2016; Djalilov ve Piesse, 2016; Isik, 2017; Ozili, 2017).

Likidite riski: bankaların karlıığını araştıran çalışmalarda sıklıkla kullanılan ikincisi risk türü ise likidite riskidir. Kredi riskinin (düşük aktif kalitesi) yansıra likidite riski (düşük likidite) de sektörde bankaların başarısız olmalarına neden olan önemli faktörlerin başında gelmektedir (Djalilov ve Piesse, 2016; Isik ve Ince, 2016; Aydemir ve Guloglu, 2017; Caporale vd., 2017). 
Bu çalışmada likidite riski, likit varlıkların toplam varlıklara oranının tersi ile ölçülmüştür. Finans teorisi bağlamında artan risk artan karlııkla açıklandığından, banka karlılı̆ının likidite oranının tersi ile temsil edilen likidite riski ile pozitif yönde ilişkili olması beklenir (Adusei, 2015; Işık vd., 2017).

Ekonomik büyüme: makroekonomik gelişmenin en genel ve doğrudan ölçüsü olan ekonomik büyüme, analizde reel gayrisafi yurt içi hasılanın doğal logaritmik değeri ile temsil edilmektedir. Ekonomik büyüme ölçüsü, toplam iktisadi faaliyetleri göstermesi bakımından önemlidir. Ekonomik büyümenin çeşitli yollarla banka mevduatlarının ve kredilerinin arz ve talebini etkileyerek dolaylı olarak banka karlıı̆ıını etkilemesi beklenmektedir. Ekonomik büyümeyle birlikte reel sektörün gelişmesi bankaların kredilerini geri toplayabilmesine ve yeni krediler verebilmesine olanak tanıyabilir. Ayrıca ekonomideki büyüme bankacılık sektörü için yeni iş fırsatlarının muhtemel olduğunu gösterebilir (Demirgüç-Kunt ve Huizinga, 1999; Bikker ve Hu, 2002; Alper ve Anbar, 2011; Taşkın, 2011). Bu nedenle büyümenin karlılığı pozitif etkilemesi beklenebilir.

Enflasyon: çalışmamızda karlılığı etkileyen önemli bir makroekonomik değişken olan enflasyon düzeyini temsilen 2003 bazlı tüketici fiyat endeksinin doğal logaritmik değeri kullanılmaktadır. Enflasyon, maliyetlerin, gelirlerin ve özellikle sektörün net varlıklarının reel değerini etkilemektedir. Enflasyon ve banka karlılığı arasında ilişki enflasyonun öngörülebilir ve öngörülemez olmasına bağlı olarak değişebilir. Enflasyonun öngörülebilir olması durumunda banka yönetimi faiz oranını hızlı şekilde ayarlayabilir ve gelirleri maliyetlerinden daha fazla arttırarak karlılığı pozitif etkileyebilir. Ancak enflasyonun öngörülememesi halinde, banka yönetiminin faiz oranlarının düzenlenmesindeki gecikmesi enflasyona bağlı maliyetlerin gelirlerden daha fazla artmasına ve karlılığı negatif etkilemesine neden olabilir. Dolayısıyla enflasyon ve banka karlıı̆ı arasındaki ilişkinin belirsiz olması nedeniyle enflasyon değişkeninin beklenen işareti açık değildir (Perry, 1992; Bikker ve Hu, 2002; Pasiouras ve Kosmidou, 2007; Alper ve Anbar, 2011; Us, 2015; Isik ve Belke, 2017).

Politika faiz oranı: para politikalarının etkisini gösteren politika faiz oranı, Us’u (2015) takiben 2011 yılı öncesi dönem için Borsa İstanbul Repo ve Ters Repo piyasası gecelik repo oranının, 2011 yılı sonrası dönem için ise TCMB ağırlıklı ortalama fonlama maliyetinden oluşmaktadır. Politika oranı bankacılık sektörünü özellikle banka kredi kanalı yoluyla etkilemektedir. Buna göre faiz oranındaki artış bankaların ödünç verilebilir ve toplam fon arzını arttırarak karlılığı pozitif etkilemesi beklenebilir (Bikker ve Hu, 2002; Us, 2015).

Döviz kuru: makroekonomik koşullardaki değişimin etkisini göstermesi bakımından önemli olan bir diğer değişken olan döviz kuru, TCMB'nin nominal ABD dolar kuru ile temsil edilmektedir. Kurdaki bir değer kaybı, döviz yükümlülüklerini arttırabilir ve artan bu yükümlülükler karlılığı baskılayabilir (Us, 2015). Bu nedenle banka karlılığı ile döviz kuru arasında negatif bir ilişki olması muhtemeldir. Çalışmamızda döviz kuru değişkeninin işaretinin negatif olması beklenmektedir.

Piyasa yoğunlaşması: banka karlılı̆ı ve yoğunlaşma arasındaki ilişkiyi incelemek amacıyla karlılık modelinde tüm bankaların piyasa paylarının karelerinin toplanması yoluyla hesaplanan Herfindahl-Hirschman yoğunlaşma endeksi kullanılmıştır. HHI değerinin 0.1000 'in altında olması bankacılık piyasasında yoğunlaşmanın bulunmadığını, $0.1000-0.1800$ arasında olması orta derece bir yoğunlaşmanın bulunduğunu ve 0.1800 'den büyük olması piyasada yoğunlaşmanın yüksek olduğunu göstermektedir (Jansen ve Haan, 2003; Abbasoglu vd., 2007). Yapı-İşleyiş-Performans (Structure-Conduct-Performance) hipotezine göre yoğunlaşmanın yüksek olduğu sektörde tekelci karların etkisiyle banka karlılı̆ının yüksek olması beklenmektedir (Smirlock, 1985).

Tablo 2: Tanımlar ve Bağımsız Değişkenlerin Banka Karlılığı Üzerinde Beklenen Etkileri

\begin{tabular}{|c|c|c|}
\hline Değişkenler & Tanımlar & Beklenen Etkiler \\
\hline \multicolumn{3}{|l|}{ Panel A: Bağımlı değişken } \\
\hline Banka Karlılığı & Net dönem karı (zararı)/toplam varlıklar & \\
\hline \multicolumn{3}{|c|}{ Panel B: Bankaya özgü değişkenler } \\
\hline Banka büyüklüğü & Toplam banka aktiflerinin doğal logaritması & $+/-$ \\
\hline Banka sermayesi & Toplam özsermaye/toplam varlıklar & $+/-$ \\
\hline Likidite riski & $1 /$ (likit varlıklar/toplam varlıklar) & + \\
\hline Kredi riski & Takipteki krediler/toplam krediler & - \\
\hline \multicolumn{3}{|c|}{ Panel C: Makroekonomik değişkenler } \\
\hline Ekonomik büyüme & Yıllık reel gayrisafi yurt içi hasılanın doğal logaritması & + \\
\hline Enflasyon & Tüketici fiyat endeksinin doğal logaritması & $+/-$ \\
\hline Faiz oranı & Politika faiz oranı & + \\
\hline Döviz Kuru (USD) & Merkez bankasının gösterge niteliğinde belirlediği döviz kuru & - \\
\hline \multicolumn{3}{|c|}{ Panel D: Sektöre özgü bağımsız değişken } \\
\hline Yoğunlaşma endeksi (HHI) & $\begin{array}{l}\text { Sektör içindeki her bir bankanın toplam varlıklar açısından } \\
\text { paylarının karelerinin toplamı alınarak hesaplanmıştır. }\end{array}$ & + \\
\hline
\end{tabular}




\section{BULGULAR}

Tablo 3'te tüm mevduat bankalarının, borsada işlem gören ve görmeyen mevduat bankalarının için tanımlayıcı istatistikleri ile ortalama (t-testi) ve medyan (Mann-Whitney) testleri sonuçları rapor edilmiştir. Buna göre banka karlılığı değişkenin ortalaması tüm bankalar için yaklaşı \%1, borsada işlem gören (görmeyen) bankalar için yaklaşı \%1.22 (\%o 7) değerini almaktadır. Hem tüm bankalar örnekleminde hem de borsada işlem görmeyen bankalar örnekleminde karlılık ortalamaları ilgili standart sapma değerlerinden küçük olduğundan bu serilerde değişkenliğin yüksek olduğu söylenebilir.

Ortalama ve medyan testleri sonuçlarına göre, bankaya özgü değişkenler açısından iki tür banka arasında anlamlı farklılıklar bulunmakta olup bu farklılıklar istatistiki olarak \%1 önem düzeyinde anlamlıdır. Daha açık bir ifadeyle banka karlılığı, banka büyüklüğü, likidite riski ve kredi riski değişkenlerine ait ortalama (medyan) değerleri borsada işlem gören mevduat bankaları için bununla beraber banka sermayesi değişkeninin ortalama (medyan) değeri ise borsada işlem görmeyen mevduat bankaları için anlamlı bir şekilde daha yüksektir.

Tablo 3: Tanımlayıcı İstatistikler ile Ortalama ve Medyan Testleri Sonuçları

\begin{tabular}{llllllll}
\hline Değişken & & Ortalama & Medyan & SD & Minimum & Maksimum & N \\
\hline Banka karlılı̆ı & $\mathrm{A}$ & .0094871 & .0105695 & .0252201 & -.388947 & .082319 & 1012 \\
& $\mathrm{~B}$ & $.0122381^{* * *}$ & $.011291^{* * *}$ & .0121698 & -.12801 & .057773 & 484 \\
& $\mathrm{C}$ & .0069654 & .0084115 & .0327284 & -.388947 & .082319 & 528 \\
Banka büyüklüğü & $\mathrm{A}$ & 9.436293 & 9.38959 & 1.775356 & 5.69922 & 12.621 & 1012 \\
& $\mathrm{~B}$ & $10.54988^{* * *}$ & $10.83415^{* * *}$ & 1.284258 & 7.11728 & 12.5423 & 484 \\
& $\mathrm{C}$ & 8.415506 & 8.254005 & 1.53366 & 5.69922 & 12.621 & 528 \\
Banka sermayesi & $\mathrm{A}$ & .1284678 & .1184 & .0475403 & .0518 & .4921 & 1012 \\
& $\mathrm{~B}$ & .1165163 & .1137 & .0246619 & .0593 & .2423 & 484 \\
& $\mathrm{C}$ & $.1394233^{* * *}$ & $.12925^{* * *}$ & .0593876 & .0518 & .4921 & 528 \\
Likidite riski & $\mathrm{A}$ & 2.926911 & 2.85181 & 1.130116 & 1.06156 & 9.4274 & 1012 \\
& $\mathrm{~B}$ & $3.026741^{* * *}$ & $2.967675^{* * *}$ & .7635768 & 1.38365 & 6.10838 & 484 \\
Kredi riski & $\mathrm{C}$ & 2.8354 & 2.61165 & 1.377752 & 1.06156 & 9.4274 & 528 \\
& $\mathrm{~A}$ & .0384743 & .031679 & .0314307 & 0 & .271226 & 1012 \\
& $\mathrm{~B}$ & $.0436765^{* * *}$ & $.0380985^{* * *}$ & .0310087 & .005798 & .271226 & 484 \\
\hline Ekonomik büyüme & $\mathrm{C}$ & .0337055 & .026001 & .0310848 & 0 & .194436 & 528 \\
Enflasyon & & 19.47865 & 19.43 & .1824609 & 19.12 & 19.8448 & 1012 \\
Politika faizi & & 5.175026 & 5.17983 & .2491383 & 4.74148 & 5.59312 & 1012 \\
Döviz kuru & & .1075605 & .09 & .043335 & .05 & .18 & 1012 \\
Yoğunlaşma endeksi & & 1.699043 & 1.545855 & .4267947 & 1.18515 & 2.90638 & 1012 \\
\hline
\end{tabular}

Not: (A) bütün bankaları, (B) borsada işlem gören bankaları (C) borsada işlem görmeyen bankaları göstermektedir. ${ }^{* * *} \% 1$ önem seviyesinde istatistiksel anlamlılı̆ı göstermektedir.

Denklem (1)'de ifade edilen modelin tahmin sonuçları Tablo 4'te sunulmaktadır. Daha açık bir ifadeyle, Tablo 4'teki analiz sonuçları rapor edilirken birinci sütunda tüm bankalar örneklemi, ikinci ve üçüncü sütunlarda borsada işlem gören bankalar ve borsada işlem görmeyen bankalar örneklemleri dikkate alınmıştır.

Model tahminlerinde öncelikle hangi tahmincinin en uygun tahminci olduğuna karar vermek için sırasıyla F-testi ${ }^{2}$, Breusch and Pagan LM testi ${ }^{3}$ ve Hausman testi ${ }^{4}$ yapılmıştır. En uygun tahminci belirlendikten sonra regresyon modellerinde otokorelasyon olup olmadığını sınamak için Wooldridge testi $i^{5}$, hata terimlerinin varyansının değişip değişmediğini test etmek için Modified Wald ve Levene-Brown-Forsythe testleri ${ }^{6}$ kullanılmıştır (Tatoğlu, 2012). Tüm testlere ilişkin sonuçlar Tablo 4'ün alt kısmında rapor edilmiştir.

Tablo 4'teki sonuçlar incelendiğinde tüm örneklemler için banka büyüklüğünün banka karlılığı üzerindeki etkisinin pozitif ve istatistiki olarak anlamlı olduğu görülmektedir. Bu sonuçlar göstermektedir ki banka büyüklüğü arttıkça banka karlılığı da artmaktadır. Tüm örneklemler için geçerli olan bu bulgu, Sufian (2012), Adusei (2015), Petria vd. (2015) ve Menicucci ve Paolucci'nin (2016) bulgularına benzer, ancak Hoffmann (2011), Sufian ve Habibullah (2009), Uludağ ve Gökmen (2011), Trujillo-Ponce (2013), Boadi vd. (2016) ve Caporale vd.'nin (2017) bulgularından farklıdır.

\footnotetext{
${ }^{2}$ Ho: birim etkiler yoktur/sabit etkiler tahmincisine karşı OLS tahmincisi geçerlidir.

${ }^{3} \mathrm{Ho}$ : birim etkinin varyansı sıfırdır/tesadüfi etkiler tahmincisine karşı OLS tahmincisi geçerlidir.

${ }^{4}$ Ho: birim etkiler modeldeki diğer bağımsız değişkenlerle ilişkisizdir/sabit etkiler tahmincisine karşı tesadüfi etkiler tahmincisi geçerlidir.

${ }^{5} \mathrm{Ho}$ : modelde birinci dereceden otokorelasyon yoktur.

${ }^{6}$ Ho: modelde hataların varyansı sabittir.
} 
Banka büyüklüğü değişkenin yanı sıra banka sermayesi değişkeni de tüm örneklemlerde banka karlılığındaki değişimi açıklayan önemli bir değişkendir. Banka sermayesine ilişkin pozitif ve anlamlı sonuçlar sermaye yapısı daha sağlam olan bankaların sermaye yapısı daha zayıf olan bankalara göre karlılık açısından daha iyi performans gösterdiğine işaret etmektedir. Sonuçlarımız aynı zamanda önceki birçok çalışmanın (örn: Demirgüç-Kunt ve Huizinga, 1999; Goddard vd., 2004b; Sufian, 2012; Trujillo-Ponce, 2013; Petria vd., 2015; Boadi vd., 2016) sonuçlarını desteklemektedir.

Tablo 4: Mevduat Bankalarının Karlılı̆ını Belirleyen Faktörler

\begin{tabular}{|c|c|c|c|}
\hline & Bütün Bankalar & Borsaya Kote Bankalar & Borsaya Kote Olmayan Bankalar \\
\hline \multirow[t]{2}{*}{ Banka büyüklüğü } & $.0315^{* *}$ & $.0031^{*}$ & $.0432 * *$ \\
\hline & $(2.42)$ & $(1.96)$ & $(2.84)$ \\
\hline \multirow[t]{2}{*}{ Banka sermayesi } & $.1731^{* *}$ & $.1478 * *$ & $.2281^{* *}$ \\
\hline & $(2.81)$ & $(2.00)$ & $(2.93)$ \\
\hline \multirow[t]{2}{*}{ Likidite riski } & .0015 & $-.0025 *$ & $.0021 *$ \\
\hline & $(1.25)$ & $(-1.88)$ & (1.88) \\
\hline \multirow[t]{2}{*}{ Kredi riski } & -.0407 & -.0819 & -.0666 \\
\hline & $(-0.74)$ & $(-1.58)$ & $(-0.86)$ \\
\hline \multirow[t]{2}{*}{ Ekonomik büyüme } & $.0182 * * *$ & .0113 & $.0294 * * *$ \\
\hline & $(2.70)$ & $(1.07)$ & $(3.74)$ \\
\hline \multirow[t]{2}{*}{ Enflasyon } & $-.0603 *$ & .0066 & $-.1003 * *$ \\
\hline & $(-1.77)$ & $(0.77)$ & $(-2.26)$ \\
\hline \multirow[t]{2}{*}{ Politika faizi } & $.0557^{* * *}$ & $.05368^{* * *}$ & .0235 \\
\hline & $(2.51)$ & $(4.39)$ & $(0.69)$ \\
\hline \multirow[t]{2}{*}{ Döviz kuru } & -.0033 & $-.0064 * *$ & .0014 \\
\hline & $(-0.46)$ & $(-2.46)$ & $(-0.11)$ \\
\hline \multirow[t]{2}{*}{ Yoğunlaşma endeksi } & $.5783^{*}$ & .4203 & .4246 \\
\hline & $(1.87)$ & (1.17) & $(0.66)$ \\
\hline \multirow[t]{2}{*}{ Sabit } & -.4149 & -.3186 & $-.4952 *$ \\
\hline & $(-2.48)$ & $(-1.39)$ & $(-1.99)$ \\
\hline $\mathrm{F} \mu$ & $22.38^{* * *}$ & $11.51^{* * *}$ & $25.17^{* * *}$ \\
\hline BP-LM testi & $820.74 * * *$ & $235.73 * * *$ & $251.61 * * *$ \\
\hline Hausman testi & $97.82 * * *$ & 5.95 & $70.14^{* * *}$ \\
\hline Wooldridge testi & $106.434 * * *$ & $21.493 * * *$ & $155.12^{* * *}$ \\
\hline Modified Wald testi & $10416.93 * * *$ & & $4964.44^{* * *}$ \\
\hline \multicolumn{4}{|l|}{ Levene-Brown-Forsythe testi } \\
\hline wo & & $5.0045743 * * *$ & \\
\hline W50 & & $3.0733254 * * *$ & \\
\hline W10 & & $3.1860789 * * *$ & \\
\hline F-değeri & $15.87 * * *$ & & $34.54 * * *$ \\
\hline R-kare-değeri & 0.1463 & 0.1010 & 0.2118 \\
\hline Wald ki-kare-değeri & & $1321.62 * * *$ & \\
\hline Gözlem sayısı & 1012 & 484 & 528 \\
\hline Banka sayısı & 23 & 12 & 11 \\
\hline
\end{tabular}

Not: Bağımlı değişken net karın toplam varlıklara oranıdır. Otokorelasyon ve değişen varyansa karşı dirençli t-istatistikleri parantez içinde gösterilmektedir. $* * * p<0.01, * * p<0.05, * p<0.10$.

Tahmin sonuçları likidite riski değişkeni açısından incelendiğinde bu değişkene ait katsayı tüm bankaları kapsayan örneklemde anlamsız ancak diğer örneklemlerde anlamlı bulunmuştur. Daha açık bir ifadeyle, borsaya kote olan bankaları kapsayan örneklemde daha yüksek likidite riski daha düşük düzeyde karlılıkla ilişkili iken borsaya kote olmayan bankalarda daha yüksek likidite riski daha yüksek karlılıkla ilişkilidir. Likidite riskine ilişkin ulaşılan sonuçlar borsaya kote bankalar açısından finans teorisi ile uyuşmazken, borsaya kote olmayan bankalar için finans teorisini desteklemektedir. Borsaya kote olmayan bankalar açısından bulunan sonuçlar Alp vd.'nin (2010) sonuçları ile örtüşmektedir. Bununla beraber borsaya kote bankalar açısından bulunan sonuçlar Kaymak ve Bektas'in (2008) sonuçlarını desteklemektedir.

Takipteki kredilerin toplam kredilere oranlanması ile hesaplanan kredi riski değişkenin tahmin edilen katsayısı her üç banka örnekleminde de negatif bulunmuştur. Bu sonuçlara göre toplam krediler içindeki takibe düşen kredilerin miktarının artması bankaların karlıı̆ı̆ı ters yönde etkilemektedir ancak bu değişkenin etkisi herhangi bir önem seviyesinde anlamlı bulunamamıştır. Athanasoglou vd. (2008), Trujillo-Ponce (2013), Dietrich ve Wanzenried (2014), Isik ve Ince (2016), Menicucci ve Paolucci (2016) ve Isik (2017) çalışmalarında kredi riski ile banka aktif karlılı̆ı arasında negatif ve anlamlı sonuçlar rapor etmişlerdir. 
Analiz sonuçları makro değişkenler açısından incelendiğinde tüm örneklemlerde beklendiği gibi ekonomik büyüme değişkeni ile banka karlılığı arasında pozitif bir ilişki tespit edilmiştir. Ekonomik büyümenin etkisi hem tüm örneklemde hem de borsaya kote olmayan bankalar örnekleminde istatistiksel olarak anlamlıdır. Sonuçlar göstermektedir ki ekonomik büyüme bankaların karlıık düzeyinin artmasına katkıda bulunmaktadır. Karlılık konjonktürün yükselme dönemlerinde artmaktadır. Daha açık bir ifadeyle bankalar ekonominin büyümesine bağlı olarak artan kredi taleplerini ve yeni iş fırsatlarını değerlendiren bankalar daha yüksek karlılık düzeyine sahiptir. Büyüme oranı açısından ulaştığımız bulgular Williams (2003), Gülhan ve Uzunlar (2011), Turgutlu (2014), Chronopoulos vd. (2015), Boadi vd. (2016), Işık vd. (2017), Caporale vd.'nin (2017) bulguları ile örtüşmektedir.

Enflasyon değişkenine ait katsayılar hem tüm örneklemde hem de borsada işlem görmeyen bankalar örnekleminde negatif ve istatistiksel olarak anlamlı bulunmuştur. Negatif katsayılar göstermektedir ki yüksek enflasyon bankaların karlarının erimesine yol açmaktadır. Daha açık bir ifadeyle hem tüm bankalar örnekleminde hem de borsada işlem görmeyen bankalar örnekleminde ulaşılan negatif sonuçlar enflasyonu tahmin edebilme konusunda bankaların başarısız olduklarını göstermektedir. Ayrıca artan fiyat istikrarsızlığın getirdiği makroekonomik istikrarsızlık ortamı özellikle borsada işlem görmeyen bankalar üzerinde kuvvetli etkiye sahiptir. Enflasyon oranına ilişkin sonuçlarımız Akbaş (2012), Djalilov ve Piesse (2016), Boadi vd.'nin (2016) sonuçlarına benzer, ancak Demirgüç-Kunt ve Huizinga (1999), Athanasoglou vd. (2008), Taşkın (2011), Caporale vd.'nin (2017) sonuçlarından farklıdır.

Tablo 4'teki tahmin sonuçları para politikasındaki değişimin etkisini gösteren politika faiz oranı değişkeninin katsayısının borsaya kote olmayan bankalar örneklemi dışında diğer iki örneklemde \%1 önem düzeyinde istatistiki olarak anlamlı olduğunu göstermektedir. Bulgular, faiz oranlarının bankaların karlıı̆ını arttırdığını, ayrıca bu artan faiz ortamından özellikle borsada işlem gören bankaların daha kazançlı çıktığını vurgulamaktadır. Banka karlıı̆ıının politika faiz oranından olumlu yönde etkilendiğini gösteren bu sonuç Us'un (2015) çalışmasında küresel finansal kriz sonrası dönemi kapsayan örneklemde ulaşılan sonuçlar ile örtüşmektedir.

Borsada işlem gören bankalar örnekleminde döviz kurunun tahmin edilen katsayısı negatif ve istatistiksel olarak anlamlıdır. Bu sonuca göre döviz kurundaki bir artış borsada işlem gören bankaların karlılığı üzerinde olumsuz ve belirgin bir etkiye sahiptir. Inceleme döneminde kur riskindeki artış, banka yükümlülüklerini arttırarak karlılığa negatif etkide bulunmuştur. Küresel finansal kriz sonrasını kapsayan örnekleminde Us (2015) döviz kurunun Türk bankalarının bilanço yapısı üzerinde negatif ve istatistiki olarak anlamlı sonuçlar tespit etmiştir.

Regresyon modellerinde sektöre özgü değişken olarak kullanılan Herfindahl-Hirschman Index (HHI) yoğunlaşma endeksi değişkeninin banka karlılığı üzerindeki etkisi tüm örneklemlerde pozitiftir ancak bu etki sadece tüm bankaları kapsayan örneklemde istatistiksel olarak anlamlı bulunmuştur. Tüm bankaları kapsayan örneklem için ulaşılan bu sonuç yüksek oranda banka yoğunlaşmasının sektördeki rekabeti azaltarak yüksek düzeyde karlılığa neden olduğunu öne süren Yapıİsleyiş-Performans hipotezini desteklemektedir. Yoğunlaşma endeksine ilişkin olarak Gülhan ve Uzunlar (2011), Hoffmann (2011), Turgutlu (2014) ve Trujillo-Ponce (2013) pozitif bulgular, ancak Akbaş (2012) ve Chronopoulos vd. (2015) negatif bulgular tespit etmişlerdir.

Analize dahil edilen açıklayıcı değişkenlerin ne yönde banka karlılığı değişkenini etkilediklerine ilişkin özet sonuçlar aşağıdaki tabloda sunulmaktadır.

Tablo 5: Mevduat Bankalarının Karlılığının Belirleyicilerine ilişkin özet sonuçlar

\begin{tabular}{|c|c|c|c|}
\hline & Bütün bankalar & Borsaya kote bankalar & Borsaya kote olmayan bankalar \\
\hline Banka büyüklüğü & Pozitif ilişki & Pozitif ilişki & Pozitif ilişki \\
\hline Banka sermayesi & Pozitif ilişki & Pozitif ilişki & Pozitif ilişki \\
\hline Likidite riski & iliş̧ki yok & Negatif ilişki & Pozitif ilişki \\
\hline Kredi riski & İlişki yok & İlişki yok & İlişki yok \\
\hline Ekonomik büyüme & Pozitif ilişki & illişki yok & Pozitif ilişki \\
\hline Enflasyon & Negatif ilişki & İlişki yok & Negatif ilişki \\
\hline Politika faizi & Pozitif ilişki & Pozitif ilişki & İlişki yok \\
\hline Döviz kuru & İlişki yok & Negatif ilişki & İlişki yok \\
\hline Yoğunlaşma endeksi & Pozitif ilişki & ìlişki yok & illişki yok \\
\hline
\end{tabular}

\section{SONUÇ VE DEĞERLENDIRME}

Bu çalışmada, Türk bankacılık sektöründe faaliyette bulunan mevduat bankalarının aktif karlılığı üzerinde etkili olan bankaya özgü, sektöre özgü ve makroekonomik faktörler incelenmiştir. 2005Ç1-2015Ç4 dönemini kapsayan çalışmada 12'si borsada işlem gören ve $11^{\prime} i$ borsada işlem görmeyen bankalar olmak üzere toplam 23 banka analiz edilmiştir. 
Ortalama ve medyan test sonuçlarına göre bankaya özgü değişkenler açısından borsada işlem gören bankalar ile borsada işlem görmeyen bankalar arasında anlamlı farklılıklar tespit edilmiştir. Daha açık bir ifadeyle, borsada işlem görmeyen mevduat bankaları ile kıyaslandığında borsada işlem gören mevduat bankalarının aktif karlılığı, aktif büyüklüğü, likidite riski ve kredi riski daha yüksek iken özsermaye düzeyi daha düşüktür.

Regresyon analizlerinde tüm bankaları kapsayan örneklem için mevduat bankalarının aktif karlılığı üzerinde etkili olan faktörler sırasıyla banka büyüklüğü, banka sermayesi, ekonomik büyüme, enflasyon, politika faiz oranı ve piyasa yoğunlaşmasıdır. Mevduat bankalarının borsada işlem görme durumuna göre örneklem iki alt örnekleme ayrıldığında, borsada işlem gören bankalar örnekleminde banka büyüklüğü, banka sermayesi, likidite riski, politika faiz oranı ve döviz kuru anlamlı değişkenler olarak bulunmuştur. Ayrıca, analiz sonuçları borsada işlem görmeyen bankalar örneklemi için değerlendirildiğinde banka büyüklüğü, banka sermayesi, likidite riski, ekonomik büyüme ve enflasyonun banka karlılığındaki değişimi açıklayan anlamlı değişkenler olduğu tespit edilmiştir.

Çalışma, borsada işlem gören ve görmeyen bankalar için karlılığın belirleyicilerinin farklılaşmasını ileri sürmesi bakımından politika yapıılar için önemli çıkarımlar sağlayabilir. Bu nedenle bankaların performansını ve karlılığını etkileyebilecek düzenlemelerin ve politikaların sektördeki bu ikili yapıyı göz önünde bulundurması gerekmektedir. Ayrıca küresel finansal kriz özellikle likidite ile risklerin ön plana çıkmasını sağlamıştır. Bulgular bu açıdan değerlendirildiğinde borsada işlem görmeyen bankaların likidite riski konusunda daha ihtiyatlı olmaları gerekmektedir.

Çalışma özellikle veri setinin sınırlı olması nedeniyle bazı kısıtlara tabi bulunmaktadır. İlerideki çalışmalar sektörde farklı taleplere de cevap verebilen katılım bankalarının karlılığının belirleyicilerini inceleyebilir. Ayrıca banka-temelli önemli risklerden olan kredi riskinin kredi türlerine (tüketici kredileri, emlak kredisi vb.) göre karlılık üzerindeki etkilerinin değişip değişmediği araştırılabilir. Ayrıca elde edilen bulguların gelişmekte olan ülkeler arasında anlamlı olup olmadığının değerlendirilmesi için çalışma birçok gelişmekte olan ülkeyi dahil ederek genişletilebilir.

\section{KAYNAKÇA}

Abbasoğlu, O.F., Aysan, A.F. \& Güneş, A. (2007). Concentration, competition, efficiency and profitability of the Turkish banking sector in the post-crisis period. Banks and Bank Systems, 2(3), 106-115.

Adusei, M. (2015). Bank profitability: Insights from the rural banking industry in Ghana. Cogent Economics \& Finance, 3(1), 1078270.

Akbaş, H.E. (2012). Determinants of bank profitability: An investigation on Turkish banking sector. Öneri Dergisi, 10(37), 103-110.

Alp, A., Ban, Ü., Demirgüneş, K. \& Kılıç, S. (2010). Türk bankacılık sektöründe karlılı̆ı̆n içsel belirleyicileri. íMKB Dergisi, 12(46), 1-13.

Alper, D. \& Anbar, A. (2011). Bank specific and macroeconomic determinants of commercial bank profitability: Empirical evidence from Turkey. Business and Economics Research Journal, 2(2), 139-152.

Athanasoglou, P.P., Brissimis, S.N. \& Delis, M.D. (2008). Bank-Specific, industry-specific and macroeconomic determinants of bank profitability. Journal of International Financial Markets, Institutions, and Money, 18(2), 121-136.

Aydemir, R. \& Guloglu, B. (2017). How do banks determine their spreads under credit and liquidity risks during business cycles?. Journal of International Financial Markets, Institutions and Money, 46, 147-157.

Barros, C.P., Ferreira, C. \& Williams, J. (2007). Analysing the determinants of performance of best and worst European banks: A mixed logit approach. Journal of Banking \& Finance, 31(7), 2189-2203.

Başçı, E. \& Kara, H. (2011). Finansal istikrar ve para politikası. İktisat İşletme ve Finans, 26(302), 9-25.

Bikker, J.A. \& Hu, H. (2002). Cyclical patterns in profits, provisioning and lending of banks and procyclicality of the new Basel capital requirements. BNL Quarterly Review, No.221, 143-175.

Boadi, E.K., Li, Y. \& Lartey, V.C. (2016). Role of bank specific, macroeconomic and risk determinants of banks profitability: Empirical evidence from Ghana's rural banking industry. International Journal of Economics and Financial Issues, 6(2), 813-823.

Bourke, P. (1989). Concentration and other determinants of bank profitability in Europe, North America and Australia. Journal of Banking and Finance, 13, 65-79.

Caporale, G.M., Lodh, S. \& Nandy, M. (2017). The performance of banks in the MENA region during the global financial crisis. Research in International Business and Finance, 42, 583-590.

Chronopoulos, D.K., Liu, H., McMillan, F.J. \& Wilson, J.O.S. (2015). The dynamics of US bank profitability. The European Journal of Finance, 21(5), 426-443.

Demirgüç-Kunt, A., \& Huizinga, H. (1999). Determinants of commercial bank interest margins and profitability: Some international evidence. The World Bank Economic Review, 13(2), 379-408. 
Demirgüç-Kunt, A., \& Huizinga, H. (2000). Financial structure and bank profitability. The World Bank Policy Research Working Paper, No. 2430 .

Dietrich, A. \& Wanzenried, G. (2011). Determinants of bank profitability before and during the crisis: Evidence from Switzerland. Journal of International Financial Markets, Institutions, and Money, 21, 307-327.

Dietrich, A. \& Wanzenried, G. (2014). The determinants of commercial banking profitability in low-, middle-, and high-income countries. The Quarterly Review of Economics and Finance, 54(3), 337-354.

Djalilov, K., \& Piesse, J. (2016). Determinants of bank profitability in transition countries: What matters most?. Research in International Business and Finance, 38, 69-82.

Fase, M.M.G., \& Abma, R.C.N. (2003). Financial environment and economic growth in selected Asian countries. Journal of Asian Economics, $14,11-21$.

Goddard, J., Molyneux, P. \& Wilson, J.O.S. (2004a). Dynamics of growth and profitability in banking. Journal of Money, Credit and Banking, 36(6), 1069-1090.

Goddard, J., Molyneux, P. \& Wilson, J.O.S. (2004b). The profitability of European banks: A cross-sectional and dynamic panel analysis. Manchester School, 72(3), 363-381.

Gülhan, Ü. \& Uzunlar, E. (2011). Bankacılık sektöründe kârlılığı etkileyen faktörler: Türk bankacılık sektörüne yönelik bir uygulama. Atatürk Üniversitesi Sosyal Bilimler Enstitüsü Dergisi, 15(1), 341-368.

Hoffmann, P. S. (2011). Determinants of the profitability of the US banking industry. International Journal of Business and Social Science, 2(22), 255-269.

Isik, O. (2017). Internal determinants of profitability of state, private and foreign owned commercial banks operating in Turkey. Journal of Economics, Finance and Accounting (JEFA), 4(3), 342-353.

Işık, Ö. \& Belke, M. (2017). An empirical analysis of the determinants of net interest margins of Turkish listed banks: Panel data evidence from post-crisis era, Sosyoekonomi, 25(34), 227-245.

Isik, O., \& Bolat, S. (2016). Determinants of non-performing loans of deposit banks in Turkey. Journal of Business, Economics and Finance, 5(4), 341-350.

Isik, O. \& Ince, A.R. (2016). Board size, board composition and performance: An investigation on Turkish banks. International Business Research, 9(2), 74-84.

ışık, Ö., Yalman, I.N. \& Koşaroğlu, Ş.M. (2017). Türkiye'de mevduat bankalarının kârlılığını etkileyen faktörler. İşletme Araştırmaları Dergisi, 9(1), 362-380.

Jansen, D. \& Haan, J. (2003). Increasing concentration in European banking: A macro-level analysis. De Nederlandsche Bank Research Departmant, Research Memorandum Wo No.743.

Kaymak, T. \& Bektas, E. (2008). East meets west? Board characteristics in an emerging market: Evidence from Turkish banks. Corporate Governance, 16(6), 550-561.

King, R.G., \& Levine, R. (1993). Finance and growth: Schumpeter might be right. The Quarterly Journal of Economics, 18(3), 717-737.

Levine, R. (1997). Financial development and economic growth: Views and agenda. Journal of Economic Literature, 35(2), 688-726

Menicucci, E., \& Paolucci, G. (2016). The determinants of bank profitability: Empirical evidence from European banking sector. Journal of Financial Reporting and Accounting, 14(1), 86-115.

Miller, S.M. \& Noulas, A.G. (1997). Portfolio mix and large-bank profitability in the USA. Applied Economics, 29, 505-512.

Molyneux, P. \& Thornton, J. (1992). Determinants of European bank profitability: A note. Journal of Banking and Finance, 16, 1173-1178.

Ozili, P.K. (2017). Bank profitability and capital regulation: Evidence from listed and non-listed banks in Africa. Journal of African Business, $18(2), 143-168$

Pasiouras, F. \& Kosmidou, K. (2007). Factors influencing the profitability of domestic and foreign commercial banks in the European Union. Research im International Business and Finance, 21(2), 222-237.

Perry, P. (1992). Do banks gain or lose from inflation?. Journal of Retail Banking, 14(2), 25-40.

Petria, N., Capraru, B. \& Ihnatov, I. (2015). Determinants of banks' profitability: Evidence from EU 27 banking systems. Procedia Economics and Finance, 20, 518-524.

Rashid, A. \& Jabeen, S. (2016). Analyzing performance determinants: Conventional versus Islamic banks in Pakistan. Borsa Istanbul Review, 16(2), 92-107.

Short, B.K. (1979). The relation between commercial bank profit rates and banking concentration in Canada, Western Europe and Japan. Journal of Banking and Finance, 3, 209-219. 
Smirlock, M. (1985). Evidence on the (non) relationship between concentration and profitability in banking. Journal of Money, Credit and Banking, 17(1), 69-83.

Sufian, F. (2012). Determinants of bank profitability in developing economies: Empirical evidence from the South Asian banking sectors. Contemporary South Asia, 20(3), 375-399.

Sufian, F. \& Habibullah, M.S. (2009). Bank specific and macroeconomic determinants of bank profitability: Empirical evidence from the China banking sector. Frontiers of Economics in China, 4(2), 274-291.

Tan, Y. (2016). The impacts of risk and competition on bank profitability in China. Journal of International Financial Markets, Institutions and Money, 40, 85-110.

Taşkın, F.D. (2011). Türkiye'de ticari bankaların performansını etkileyen faktörler. Ege Akademik Bakış, 11(2), 289-298.

Tatoğlu, F.Y. (2012). Panel veri ekonometrisi. Beta Yayıncılık, İstanbul.

Trujillo-Ponce, A. (2013). What determines the profitability of banks? Evidence from Spain", Accounting \& Finance, 53(2), 561-586.

Turgutlu, E. (2014). Dynamics of profitability in the Turkish banking industry. Ege Akademik Bakış, 14(1), 43-52.

Uludağ, B.K. \& Gökmen, H. (2011). Türk bankacılık sektörünün kârlılı̆ının dinamik yaklaşımla test edilmesi. s, V. (2015). Banking sector performance in Turkey before and after the global crisis. İktisat İşletme ve Finans, 26(308), 71-98.

Us, V. (2015). Banking sector performance in Turkey before and after the global crisis. İktisat işletme ve Finans, 30(353), 45-74.

Williams, B. (2003). Domestic and international determinants of bank profits: foreign banks in Australia. Journal of Banking and Finance, 27(6), 1185-1210. 